\title{
Belle Doyle, location manager
}

Belle Doyle was the premier location manager in Scotland for nearly a decade, with appointments at both Scottish Screen and Creative Scotland, where she worked on a range of local and international productions, including Red Road (2006), Doomsday (2008), The Dark Knight Rises (2012), and World War Z (2013). Throughout her career she has been active in mobilizing resources for the Scottish motion picture industry. Here she reflects on the country's place in the greater UK production economy, with particular attention given to the plight of local film and television practitioners.

You left Glasgow for the southwest of Scotland. Why did you leave your post at Creative Scotland?

I was working too many hours a day. Tons of travel every few weeks. I was always on some transatlantic or European flight. I was going to Los Angeles, Cannes, Toronto, Hong Kong. I also was very involved with the Association of Film Commissioners International [AFCI]. I attended a number of AFCI board meetings, conferences, and meet-ups with counterparts in other countries. I was visiting film studios as well to see how they worked and what the model could potentially be for Scotland. It was never-ending. I started having health issues. My blood pressure was high, and I had gained loads of weight. It got to a point-you know, I'm fifty-where my body was telling me I was working too much. It's all glamorous and lovely for a while, but then there's a moment of realization when you say to yourself, I'd rather be home watching telly with a cup of tea than attending another party at Cannes. 
The southwest is a beautiful part of the country. It's rural and laid back with a big arts community. I still do bits of scouting work, but because I'm so involved in the arts scene here, I don't have time for much else.

\section{You've spoken openly about your frustrations with Creative Scotland.}

It was certainly part of the problem for me. We lost our dedicated film agency [Scottish Screen] when it was dissolved to form this much larger arts agency [Creative Scotland]. As a result, film became just another art form. No one recognized or understood it as an industry and a business. And that became very frustrating to me. I had enjoyed working with and on behalf of the industry, and I wasn't able to do that working for Creative Scotland. The agency's unwillingness to engage the film community in that way made my job feel very unproductive and limited. I remember thinking: I don't have to do this anymore. In fact, I can have a bit more free time as a freelancer. I will no longer have to speak on behalf of the government. I can step outside the party line to say what I really think.

So what can you tell us now that you couldn't tell us then?

The bodies! Where the bodies are buried! [Laughter]

There was a party line for even the most basic things, like, does Scotland need a film studio? The official answer was, "No. People come here to film on location. We don't need any infrastructure. We don't need an incentive. Everything's fine." No! Everything is not fine. We need a studio and an incentive. Again, the agency believed film was an art form and there was no need to discuss how to develop it as a business. I couldn't even have conversations with my counterparts at Scottish Enterprise and Scottish Development International [business development agencies]. It didn't make sense within the institutional culture of the agencies or their funding strategies. SE and SDI support business development and research but don't recognize film or television. Then you have the arts agency where I worked that supports the creative aspects of film and television but didn't see the business side as its concern. So film and television ended up in this massive black hole with no one trying to nurture it into a sustainable and viable national industry. There's been some recent acknowledgment from the government that this is an oversight that needs to be fixed, but it remains frustrating.

There is a specific Scottish way of doing things in the public sector: we schedule meetings, discuss the issues, write reports, and hire consultants. It takes an incredibly lengthy amount of time and often produces little in the way of results. We've been debating a film studio for three decades! I became very uncomfortable justifying the slowness of the agency's decision making-their decisions and overall lack of support for the sector. It wasn't really my responsibility to justify it, but I was a public servant working for the agency; I had lots of relationships with the film community, so I frequently found myself having to explain their logic. I'm not 
someone who can shut down her computer at five every day and then go home and not worry about things.

\section{What were some of the things that worried you?}

Right now the local film sector survives as a gift economy. For instance, we have excellent postproduction service companies in Glasgow, like the Savalas sound studio, but they can't operate with sustainable business models by relying on local productions alone. They are offering their state-of-the-art facilities at reduced rates for local producers simply because they [local producers] can't pay the company's standard fees. So, we have a renowned company accepting lower rates or doing favors for local producers in order to help out the indigenous film sector. It's a recurring and persistent problem across the sector as a whole. It's no way to run a single business, and it's no way for an entire sector to thrive.

Why do service providers do it?

Because producers haven't raised the finances or simply can't afford it. Or the service provider will think about it realistically: I'll just accept the lower rate because it's unlikely I'll see any money from the producer anyway.

Do they do it because they have a noneconomic-call it a moral, ethical, or nationalist-investment in seeing Scottish film flourish despite the sector's limited resources?

I think so. There is a palpable desire among those of us who live and work here to see the sector thrive.

\section{More so than other locations?}

Absolutely. Service providers won't do massive amounts of work for local producers. They are more willing to help micro-budgeted projects or emerging filmmakers, which is great and should be encouraged. In fact, all local facilities and service providers go out of their way to do that. That's great. That's how people make their first films. But on your third film, you shouldn't still be asking for favors. You made a promise. You said, "I'm on my way up. When I'm successful, I'll pay you properly."

A gift economy is not a very reassuring long-term business strategy. How does a company like Savalas survive?

Because Scotland is part of the UK, local facilities and service providers bid for larger UK-level projects. Companies here are members of the UK Screen 
Association. They can bid for work coming to SoHo [in London]. It's the only way they can survive, but competition for that work is fierce, too. Yet this is the sort of big-picture thinking that a local film industry needs to survive. We need to think beyond our borders to help what happens within our borders.

\section{Where's the breakdown, then?}

We don't have any sales agents or distributors. I can name one company here, but they only distribute old films, not new material. When you don't have direct access to the market, you are working with firms that you don't know and that don't know you. We're left with so few options that we have very little negotiating power. Producers are eager to sign all of their rights away just to make the film. When you do that, you don't see any returns. You're left with nothing to invest in your next project. I think Sigma Film's Gillian Berrie is probably the only local producer in a position to make some money to reinvest in subsequent films. I can name one! Again, this isn't a realistic business model. But when you're trying to make films in a country with so little support, you're left with few choices.

Let's make sure we understand what you're saying: producers are selling any and all rights they have to their intellectual property to finance the production up front, and then it's completely out of their hands when (or if) it's released. Nothing comes back to their coffers.

Like I said, it's a completely unsustainable model that requires everyone to do favors for everyone else. I have traveled to Los Angeles and London quite a bit. You meet people there who want to get into the industry to make money. You don't hear people say that in Scotland.

It sounds like a film-school mentality on a national scale.

I couldn't have said it better myself. People are working for free. People are maxing out credit cards. And these aren't students but producers and production companies. There's still this film-school mentality: I have this vision, and this is how I want to realize this vision. No one looks at it in black-and-white terms. What can I actually do with the resources I have? What can I afford? How long might it take me to develop the project to ensure I can afford it? Can I pay people?

Let's switch gears from the creative process and financial decisions to talk more about the crew. They have been one of the most vocal contingents advocating for a studio. What are working conditions like on indigenous films? 
That's not reassuring! Let's talk specifics. Black Camel's Outpost (2008) was a relatively successful genre picture. It played in the United States. It sparked a small horror franchise. Aren't there three films now?

They financed the first installment with their credit cards and by mortgaging their home. I don't know what distribution deal they had with Sony, but I've heard it wasn't great.

\section{But working on that film?}

One of the things they did on the film that upset a lot of folks was hire local art students to paint sets for nothing. They worked twenty-hour days for no pay. But they thought, "Glamour! Film!" They reported to a well-respected production designer who made sure the production values were outstanding-and the film looks fantastic! People want to do their best here. They care about the art and the craft. It's why outsiders are always impressed with local crew-the professionalism, commitment, and standards of work you find here are second to none.

How can you get away with twenty-hour workdays with students? Where was the union?

BECTU is largely ineffectual in Scotland. It essentially ignores the film sector. The union rep here is not sharp enough to run around and police all of the violations, likely because the projects are so under-resourced and underfunded that he couldn't keep up. But this leads to other problems: a production culture that makes certain things "okay," even on sets that can afford to (and should) do better. Unfortunately, union membership in Scotland is quite low as a consequence, because people don't see the value in it: Why pay dues for something that won't protect you?

Right now it's a bit of a free-for-all. We don't adhere to the working time directives enforced in other European countries, so sixteen-hour days on set are standard here. I also think there's an implicit threat on film sets: This is what you wanted to do. You're lucky to be doing it. Why complain?

You'll also often hear from producers, "Here are the BECTU rates, but what are your rates? What will you work for?" Crew constantly undercut each other's rates. You're supposed to place a value on your labor during negotiations, but because work is scarce, you never want to push too hard. If they don't like your rate, they don't have to hire you. Likewise, if you really want to work on a particular film, you can value your labor at a point you know is lower than other people up for the job. This process ultimately drives down everyone's wages, especially women. 
You'll find the heads of departments have negotiated rates, but if she is a woman, it's always oddly lower than her male counterparts.

It's even worse when you're dealing with visiting producers from Hollywood or London. They will want to hire someone to location scout in Scotland but not pay him or her the official rate for doing so. You wouldn't ask somebody in London to work for a lower rate. Why us? For some reason, when production companies come here, they immediately think everybody in Scotland should be cheaper, which irritates people here. We're performing the same roles. We're highly trained and highly skilled. Why are we less valued?

A local location manager was so tired of it happening that he started rallying location scouts in the area, asking them not to accept anything lower than the standard rate. It was exciting to see people become extremely vocal about it, but it's a difficult proposition. People need to work. People need to eat. It's another way crew undercut each other. A producer will call for a scout and say, "I know I'm supposed to pay you 250 pounds a day, but we can only afford 200." How can you blame people for accepting the offer when they know the next person the producer calls will say yes?

But the producer is thinking that Glasgow must be cheaper than London.

I agree. You'll save some money on accommodations, and on catering. Permits and logistics are less costly. You won't pay local government the same thing here as you do in London. You can shoot something in the middle of the city, and it won't cost you what it would cost you to shut down the center of London. I get it. But people aren't cheaper. Skilled labor isn't cheaper. Why should your camera hire in Glasgow-who is performing the same tasks as any other camera hire-be cheaper than a camera hire in London? We're the same country. Labor doesn't magically become cheaper just because you cross the border from England to Scotland.

You've mentioned pay rates, long hours, and an impotent union. Are those the three biggest concerns?

I would add access to work. Is it too much to expect that people can find work where they live? Isn't it a fair expectation for someone who lives in Glasgow to work in Glasgow? Right now the UK incentive allows productions to take on crew from anywhere in the UK. So, they'll crew up in London. It creates this vicious cycle: anyone from Glasgow who wants to work ends up traveling to London to look for a production job. It's an even crueler irony when they get hired in London to return for a location shoot in Scotland.

Ultimately, anyone who is any good in Scotland ends up leaving. People are going everywhere; there's so much moving around. There are lots of people 
working in Belfast on Game of Thrones (2011-ongoing). There are huge staffing shortages in Manchester right now, so people are rushing there to get work. Cardiff. Dublin. There is a huge Scottish contingent filming a Channel 4 series called Indian Summers (2015-16) in Malaysia. They are happy-it's beautiful and they're not working in the pouring rain. They're enjoying the sunshine. It's a bit of a novelty for them! But how long does that last before you tire of it? How do you settle down and have a family? You eventually reach a point where you don't want to do it anymore. Or you reach a point where your mind or body won't let you.

\section{Are there job categories where people can expect to work regularly in Scotland?}

I knew you were going to ask me this question. I've given it a lot of thought. I think location managers are the one group of film professionals here who possess such unique skills and talent and knowledge that they are absolutely key local hires. They don't chase work elsewhere as much as other people in Scotland. They aren't going to London. Look, we lack a studio. Everything filmed here is filmed on location. It's not impossible for someone who isn't from here to manage locations, but he or she will still need a local hire to help navigate a set of relationships and issues that are very unique to Scotland. So location managers always are in demand.

Actually, I think Scotland is a unique case because of the peculiar demands on the location department here. I don't think a local hire is as necessary in other places, but here location managers will read the script, break down the script, scout locations, make suggestions, and manage those locations. They are 100 percent responsible for the locations-sometimes they are managing twenty different locations! I know in the States the individuals who manage locations aren't necessarily scouting them. But here we do everything. We have to do everything.

\section{Why?}

We wear so many hats. We are mediators. We are facilitators. We hold the keys to the city. We know the right questions to ask the right people. What location best matches your needs? How do you get access to this space? What permissions do you need to do what you want to do? What rental car companies or hotels are best? We are a vast resource of local knowledge, and that helps ensure the production is not only spending their money locally but also happy with their experience filming here. It lowers the chances of missteps when you work with someone who has local knowledge.

Like I said, I think Scotland is an especially important place for the location department. Without a studio, it's the primary-the only-reason productions 
come here. So many of the requests involve very specific period details. If a producer needs a street for a nineteenth-century drama, we know where to look. We also know there isn't just one street for nineteenth-century drama. Do you want urban or rural? What social class are the characters? Do you want an upper-middle-class street? It's a very specific process here because we can find that variety. It's even more detailed when it comes to castles. Preservation is so much better here than in England or other countries. Castles are immaculately maintained. So we can find a lot of variety, but we also know how tricky it is to get permission to film in these precious historical sites. We know the rules. We know what you can or cannot do. We gain access to key historical sites and then are responsible for protecting them during filming. All of this makes locations a very specialized skill set in Scotland.

\section{Are good location managers proactive or reactive?}

Reactive, always. It's the nature of the job. They're always responding to someone saying, "I need this." Even if they're reading the script, they're responding to what they think it requires, and then negotiating with other members of the production team to match their vision of the right location with other ideas. In fact, that's a key strength: you have to be very good with people. You have to be an excellent communicator and collaborator.

\section{What types of individuals make the best location managers?}

The very best are the ones who stick with it. They are professional. They are committed to training up younger people. But it's a hellish job. People often don't do it for very long.

\section{What makes it such an immense responsibility?}

Lots of people view the location department as an avenue through which to become a production manager. Nobody in London wants to be a location manager. It means getting up early, going home late. It means running around, sometimes miles and miles at a time, between different locations. Everyone's gunning for you. You are responsible for everything, and the logistics of the job are so difficult, especially in Scotland, where we often negotiate for access to historic buildings and castles. First there are so many legal hoops to maneuver, and then you're responsible for protecting that space from damages. You need a special person who can charm the public agencies or private landowners and assure them that nothing horrible will happen in order to get the keys to their castle. 
If we gave you a magic wand, what would you change in Scotland?

We need an incentive that is linked to local crew and location spend. It needs to be in addition to the UK incentive. We also need to increase the film fund to give producers with decent scripts enough money to make their films.

\section{What about a facility?}

We need a studio. Imagine a little village shop with very few items. Someone gives you 50,000 pounds to spend in that shop. You would struggle to spend it. I see the need for a studio in the same way. What money can productions spend if we don't offer anything for them to spend it on? It's a serious impediment. We don't need to build another Pinewood. But there is such a tiny amount of dedicated production space here, especially if you need a facility with blackout capabilities and sound insulation. Nearly all filming done here at the moment is shot on location or in converted warehouses and makeshift soundstages.

What crew positions are increasingly critical for locations that want to attract the attention of international producers?

Location managers, production managers, and line producers. Any location that wants to host global productions needs to make sure they have hometown men and women in these positions. They are the individuals who can convince producers that yes, the project can be done here or there.

\section{What's the holdup with the film studio?}

The Scottish government is still figuring out what it wants. They were starstruck when Brad Pitt was here. They were obsessed with tourism in the wake of Disney's Brave (2012). They spent 7 million pounds on a tourism campaign. Can you imagine how the film sector would have benefited from that support? Brave had nothing to do with the film industry here! At other times, they seem to want local filmmakers winning prizes at Cannes for art films.

It's also the same arts-versus-business divide that's stunted support for the sector. We have to think of film and television as an industry that requires investment. Yes, it's creative. Yes, it's cultural. But it's also an industry that creates jobs and ensures livelihoods. And it requires infrastructure and incentives to grow.

Right now local producers and crew are frustrated with the lack of any real progress. There's so much interest in filming in the UK, especially after the launch of the high-end television incentive. It's increased demand; studios are bursting 
at the seams! I think that only adds to the anger-they're tired of jumping up and down for someone to take notice that Scotland can benefit in the same way England, Wales, and Northern Ireland benefit from those productions. We could easily be working here, but opportunities keep passing us by because we have nowhere to host them. I know we lose productions and we lose work because we can't offer producers a local incentive and permanent studio. Game of Thrones is the most recent and visible example. It's just so competitive right now that we can't afford not to invest.

\section{But that's taxpayer money.}

Incentives require strategy. We need local incentives to complement the UK incentive, but we also need to include stipulations that we can police. You need to hire so many crew. You need to have at least one local department head. An incentive requires accounting and accountability, which would help us ensure that those criteria are met. Ironically, without an incentive, we can't police anything. It's hard to track down accurate figures on employment and spend because they aren't accountable to anyone in Scotland. And without a studio, productions are here for six weeks, not six months. It's absolutely frantic.

I think a film studio with the right incentive structure will change the situation. Right now international productions will pick up a local location team and local extras for second-unit shoots. They'll hire some local services-hotels and catering and restaurants-and facilities. Of course, they're paying the city for permits and security. It helps in terms of tourism and some local spend from the production while they're here. But for the most part, they're bringing all crew and equipment with them. If they are able to establish a production base here for a length of time, there's more development and prep. There's more money being spent. There's a greater need for local hires. It just seems like a no-brainer to me.

So despite the celebratory headlines about filming a key scene from World War $Z$ (2013) in Glasgow ...

There are reasons to be excited about it. In addition to what I just outlined, it proves the city is capable of hosting a production of that size-that we're film friendly. But it didn't employ a lot of local crew except for locations and extras.

I'm not suggesting that we think exclusively about Hollywood production. I'm leery of chasing the Hollywood dollar because it's becoming harder and harder to grab it from other locations that are chasing the same dollar. I'm arguing for a slightly different approach. I think a smarter strategy is to offer more support for European coproductions. Right now the current incentive in the UK isn't designed to support smaller coproductions. That creates a feasible opportunity for us. Target 
smaller, more interesting productions. Build a studio. Implement a local incentive to ensure that those productions use our facilities and our crews. It doesn't have to be a huge incentive. But if Scotland is ever going to make better films, we need to ensure that people get opportunities to train and learn.

I think an occasional blockbuster is great. It brings international investment into Scottish service providers and facilitates, which makes them even stronger because they're actually making real money. It raises our international profile. It also ensures continuity of employment. It helps train them and increase their skills. You see how things are supposed to be done. But other types of productions also offer great experiences. You're less marginalized. You have more authority, more opportunities to advance professionally. Let's put our effort and resources into films with proper financing so they can create appropriate working conditions and pay their crew and operate on a realistic budget without asking for favors. It may not be a Hollywood film but it's no less global. It's a broader perspective on the industry that the government doesn't seem to understand.

Really, my dream would be for us to cultivate productions here that are culturally and economically compelling. Films people take seriously. Films people want to see in the cinema. How can we use a studio and an incentive to develop a global audience for these sorts of films? 